\title{
Size-fractionated phytoplankton pigment groups in the NW Iberian upwelling system: impact of the Iberian Poleward Current
}

\author{
F. Rodríguez ${ }^{1, *}$, J. L. Garrido ${ }^{2}$, B. G. Crespo ${ }^{2}$, B. Arbones $^{2}$, F. G. Figueiras ${ }^{2}$ \\ ${ }^{1}$ Centro Oceanográfico de Canarias (IEO), Carretera de San Andrés s/n, 38120 Santa Cruz de Tenerife, Spain \\ ${ }^{2}$ Instituto de Investigacións Mariñas (CSIC), Eduardo Cabello 6, 36208 Vigo, Spain
}

\begin{abstract}
Size-fractionated phytoplankton was studied using pigments and carbon (C) biomass derived from light microscopy at a fixed location on the NW Iberian shelf between May 2001 and June 2002. The annual contributions of pico-, nano- and microphytoplankton to the total autotrophic C biomass were $9.7,63$ and $27.3 \%$, respectively, with unidentified nanoflagellates (63\%) and diatoms $(22 \%)$ being the most important components. The CHEMTAX program was used to determine the chlorophyll $a(\mathrm{chl}$ a) contribution of 9 pigment groups in nano-microplankton and 8 in picoplankton. 'Diatoms II' (species containing chl $C_{3}$ ), 'haptophytes II' (species of the genus Chrysochromulina containing chl $C_{2}$-MGDG [monogalactosyl diacylglyceride] [14:0/14:0] ) and 'chlorophytes', represented 34,17 and $16 \%$, respectively, of the total chl $a$ in the nano-microplankton fraction. The major pigment groups in the picoplankton were 'chlorophytes', 'Synechococcus' and 'prasinophytes II' (Order Mamiellales), which accounted for 34, 22 and $10 \%$ of the total chl $a$ in this size class. 'Prochlorococcus' was traced using divinyl (DV) chl a and was present seasonally, especially during downwelling and stratified poleward conditions (October to November). The lowest chl $a$ and autotrophic $C$ values throughout the study $\left(152 \pm 45 \mathrm{ng} \mathrm{chl} \mathrm{a} \mathrm{l}^{-1}\right.$ and $\left.31 \pm 13 \mu \mathrm{g} \mathrm{Cl}^{-1}\right)$ corresponded to the homogenous poleward flow or Iberian Poleward Current (IPC) from December to February. During this period the phytoplankton composition changed abruptly to a diverse pico-nanoplanktonic community that represented $\sim 95 \%$ of the total autotrophic C biomass. 'Chlorophytes', 'cryptophytes' and 'haptophytes II' in the nanoplankton, and 'chlorophytes' and 'Synechococcus' in the picoplankton were the main contributers to chl $a$ in IPC waters, as calculated by CHEMTAX.
\end{abstract}

KEY WORDS: Phytoplankton · Pigments · Carbon biomass · Poleward current · Iberian upwelling · CHEMTAX Resale or republication not permitted without written consent of the publisher

\section{INTRODUCTION}

Coastal phytoplankton populations experience large variations in their abundance, composition and size structure due to the dynamic nature of their environment, with potential mixing of distinct water masses of estuarine, neritic and/or open-ocean origin (Bidigare et al. 1993, Pelegrí et al. 2005). In coastal areas affected by seasonal upwelling, biological changes are even more pronounced, as nutrient-rich upwelled waters favor the dominance of large organisms (microplankton, usually diatoms) and high levels of primary pro- ductivity (Varela 1992, Prézelin et al. 2000, Tilstone et al. 2003).

Over the seasonal cycle, pico-cyanobacteria and nanoflagellates, typically haptophytes and chlorophytes (Bustillos-Guzmán et al. 1995, Rodríguez et al. 2003a), can account for a significant fraction of the productivity and biomass in coastal regions (Tilstone et al. 2003). In recent years, a wealth of studies has brought to light the true taxonomic diversity of the smallest algae, especially the eukaryotic picoplankton (e.g. Not et al. 2004, Romari \& Vaulot 2004). However, more work is needed to answer some fundamental ques- 


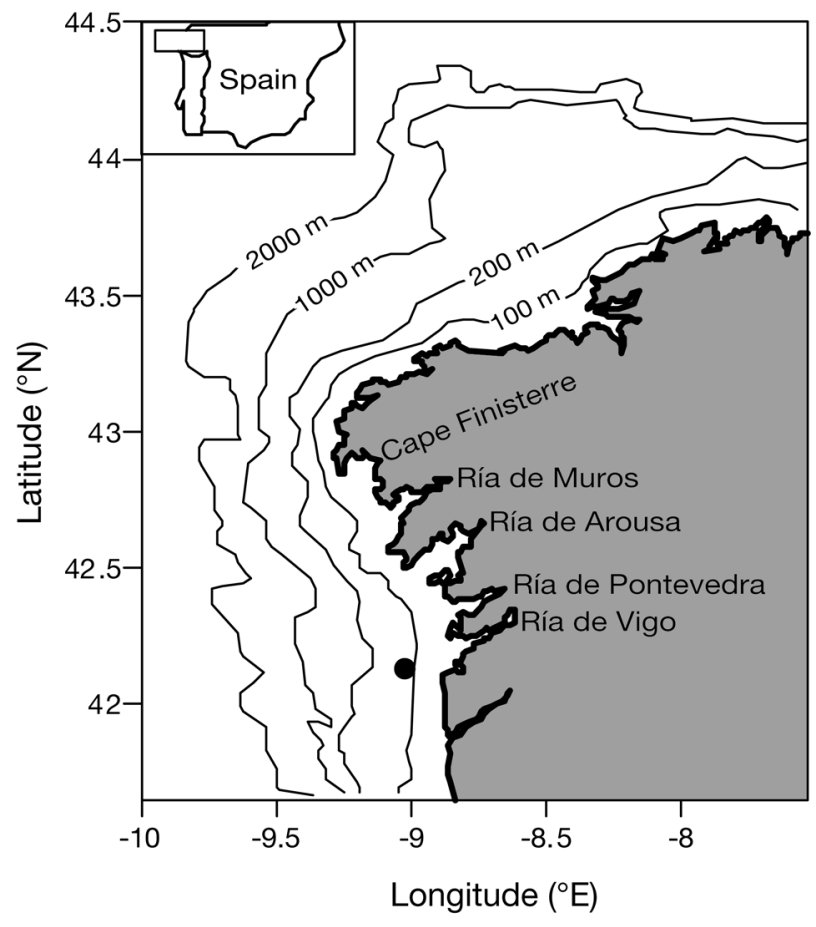

Fig. 1. Location of sampling site (๑) on the NW Iberian shelf near the Ría de Vigo

tions, such as: What are the dominant groups and what are the environmental parameters controlling their distribution in coastal versus oceanic regions?

The western Iberia Basin, which is the northern limit of the eastern North Atlantic Upwelling Region, displays high levels of primary production in coastal areas and shelf waters boosted by the seasonal upwelling (Bode et al. 1996, Joint et al. 2002). Two principal yearly periods can be distinguished in the region (Tilstone et al. 2003): the seasonal upwelling between March and October triggered by northerly winds, and the winter poleward flow or Iberian Poleward Current (IPC; Álvarez-Salgado et al. 2003, Peliz et al. 2005) associated with southerly winds from winter until early spring. The IPC is a jet of saline and relatively warm waters of subtropical origin (Peliz et al. 2005) that flows from waters south of Portugal to the NW Iberian peninsula and the southern Bay of Biscay. During winter, particularly at the core of the IPC waters, piconanoplankton communities and low chl a levels are typically observed (Álvarez-Salgado et al. 2003, Tilstone et al. 2003, Calvo-Díaz et al. 2004).

The phytoplankton composition, abundance, physiology and size distribution off the NW Iberian peninsula have been extensively studied (Figueiras \& Pazos 1991, Varela 1992, Tilstone et al. 2003). Recently, cyanobacteria and picoeukaryotes have been reported to be responsible for the fact that pico-nanoplanktonic biomass is higher on the shelf than in the Ría de Vigo
(Lorenzo et al. 2005). Unlike the microplanktonic component, the annual variability and composition of picoand nanoplanktonic eukaryotes, which also dominate IPC waters (Álvarez-Salgado et al. 2003), remain undescribed.

A previous pigment analysis of a single sample from the slope current off NW Spain (Rodríguez et al. 2003b) evidenced the presence of the cyanobacteria genera Synechococcus and Prochlorococcus with a mixture of diverse picoeukaryotic groups. Flow cytometry signatures along the coasts of the northern Iberian peninsula in winter reported that the general dominance of Synechococcus over Prochlorococcus and a major contribution of picoplankton to the total algal biomass $(\sim 60 \%)$ were accentuated in IPC waters (Calvo-Díaz et al. 2004).

In the present work, phytoplankton abundance and composition in 2 size classes (pico- and nanomicroplankton) were investigated at a fixed station off the NW Iberian coast, combining high-performance liquid chromatography (HPLC) pigment analyses and carbon (C) biomass derived from microscopic examination. The results obtained allowed, for the first time, characterization of the annual variability and composition of the pico- and nano-microplanktonic community, as well as of the size distribution and major algal groups in each size class associated with the IPC.

\section{MATERIALS AND METHODS}

Study site and sample collection. A fixed station located on the shelf near the Ría de Vigo $\left(42^{\circ} 07.8^{\prime} \mathrm{N}\right.$, $9^{\circ} 10.2^{\prime} \mathrm{W}, 150 \mathrm{~m}$ depth) was visited once a week from 15 May 2001 to 24 April 2002 (Fig. 1). Sampling was conducted using a CTD attached to a fluorometer and a rosette equipped with 101 Niskin bottles. Samples for determination of nitrate, chlorophyll, and phytoplankton levels were taken within the photic layer dur-

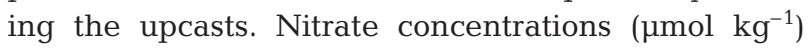
were determined by segmented flow analysis with Alpkem autoanalyzers according to Hansen \& Grasshoff (1983), with some modifications following Mouriño \& Fraga (1985).

Phytoplankton identification and carbon biomass. Microplankton samples were preserved in Lugol's iodine and sedimented in $100 \mathrm{ml}$ composite sedimentation chambers. Diatoms, dinoflagellates, flagellates $>20 \mu \mathrm{m}$, and ciliates were identified and counted at the species level, when possible, using an inverted microscope. Differentiation of phototrophic species of dinoflagellates, flagellates, and ciliates basically followed Lessard \& Swift (1986); however, epifluorescence microscopy was also used to assign phototrophs within these plankton groups. The biovolumes of each taxon 
were calculated from dimensions and shapes according to Hillebrand et al. (1999). The plasmatic volume of diatoms and total cell volume of dinoflagellates, flagellates $>20 \mu \mathrm{m}$, and ciliates were converted to cell carbon following Strathmann (1967) for diatoms and dinoflagellates, Verity et al. (1992) for flagellates, and Putt \& Stoecker (1989) and Verity \& Langdon (1984) for ciliates.

Phototrophic pico- $(\leq 2 \mu \mathrm{m})$ and nanoflagellates (2 to $20 \mu \mathrm{m}$ ) were enumerated from subsamples of $10 \mathrm{ml}$, which were fixed with buffered formalin ( $2 \%$ final concentration) and filtered on $0.2 \mu \mathrm{m}$ black Millipore polycarbonate filters placed on top of $0.45 \mu \mathrm{m}$ Millipore backing filters. An epifluorescence microscope was used to identify and count Synechococcus-type cyanobacteria and phototrophic picoflagellates and nanoflagellates. Cell biovolumes of Synechococcus were converted to carbon biomass following Fry (1990). The carbon of other pico- and nanoflagellates was estimated according to Verity et al. (1992).

Pigment analysis. Seawater samples (2 l) obtained at 4 depths within the photic layer were filtered sequentially through $47 \mathrm{~mm}$ diameter Whatman GF/D and $\mathrm{GF} / \mathrm{F}$ filters (under vacuum pressure $<100 \mathrm{mmHg}$ ) and stored at $-20^{\circ} \mathrm{C}$ until analysis. Two phytoplankton size classes were operationally defined: (1) nanomicroplankton, constituted by organisms retained on a GF/D filter (2.7 $\mu \mathrm{m}$ nominal pore size), and (2) picoplankton, consisting of organisms which passed through a GF/D but were retained on GF/F filters ( $0.7 \mu \mathrm{m}$ nominal pore size). It should be mentioned that a slight underestimation of the contribution of picoplankton using GF/D filters may have resulted in comparison with Nuclepore $3 \mu \mathrm{m}$ filters. A comparative test using both filter types would be necessary in further studies to quantify these differences in the retention capabilities and size-fractionated phytoplankton groups.

The frozen filtered samples were extracted in $5 \mathrm{ml}$ of $90 \%$ acetone using a spatula for filter grinding and further sonication over $5 \mathrm{~min}$ at low temperature $\left(\sim 5^{\circ} \mathrm{C}\right)$. Extracts were then centrifuged $(4000 \mathrm{rpm}[2862 \times g]$, $5 \mathrm{~min}, 4^{\circ} \mathrm{C}$ ) to remove cell and filter debris, and supernatants were filtered through Gelman GHP $0.2 \mu \mathrm{m}$ filters. The HPLC pigment analyses were carried out with a Waters Alliance HPLC System (2695 separation module with a 996 photodiode array detector and a 474 scanning fluorescence detector). The autosampler chamber was kept at $4^{\circ} \mathrm{C}$. Pigment separation was performed by HPLC according to Zapata et al. (2000), but slightly modified to reduce the pyridine concentration in Mobile Phase A. The stationary phase was a $\mathrm{C}_{8}$ column (Waters Symmetry: $150 \times 4.6 \mathrm{~mm}, 3.5 \mu \mathrm{m}$ particle size, $100 \mathrm{~A}$ pore size) thermostated at $25^{\circ} \mathrm{C}$. Mobile phases were: $\mathrm{A}$-methanol:acetonitrile:aqueous pyri- dine solution $(0.025 \mathrm{M}$ pyridine, $\mathrm{pH}$ adjusted to 5.0 with acetic acid) (50:25:25, v/v/v) and B - acetonitrile: methanol:acetone $(60: 20: 20, \mathrm{v} / \mathrm{v})$. A linear gradient from 0 to $40 \%$ B was pumped for $22 \mathrm{~min}$, followed by an increase to $95 \%$ at Minute 28 and an isocratic hold at $95 \%$ B for a further $12 \mathrm{~min}$. Initial conditions were reestablished by a reversed linear gradient. The flow rate was $1 \mathrm{ml} \mathrm{min}^{-1}$. Chlorophylls and carotenoids were detected by diode-array spectroscopy (350 to $7500 \mathrm{~nm}$ ). Chlorophylls were also detected by fluorescence (excitation and emission wavelengths were 440 and $650 \mathrm{~nm}$, respectively). Pigments were identified by co-chromatography with authentic standards (see Zapata et al. 2000) and by diode-array spectroscopy (wavelength range: 350 to $750 \mathrm{~nm}, 1.2 \mathrm{~nm}$ spectral resolution). Each peak was checked for spectral homogeneity using Waters Millennium ${ }^{32}$ software algorithms, and the absorption spectrum was compared with a spectral library previously created. Pigments were quantified by using external standards and extinction coefficients compiled by Jeffrey (1997).

Chlorophyll a was also determined using conventional fluorimetric procedures. Seawater samples of $100 \mathrm{ml}$ were filtered under low vacuum pressure through $25 \mathrm{~mm}$ Whatman GF/F. Filters were then immediately frozen at $-20^{\circ} \mathrm{C}$ until pigment extraction in $90 \%$ acetone over $24 \mathrm{~h}$, in darkness at $4^{\circ} \mathrm{C}$.

Pigment data processing (CHEMTAX). HPLC pigment data were processed by means of the Chemical Taxonomy program (CHEMTAX; Mackey et al. 1996). Pigment groups or chemotaxonomic classes were characterized using pigment ratios available from the literature (Table 1) and were processed using 12 marker pigments in the corresponding CHEMTAX input matrix of each size class (see Table 2). To consider changes in pigment ratios due to variable light conditions, incident photosynthetically available radiation $\left(E_{\mathrm{PAR}}\right)$ was used to distinguish 2 data sets within the CHEMTAX analyses, low light (LL, $E_{\mathrm{PAR}}<200 \mu \mathrm{mol}$ photons $\mathrm{m}^{-2} \mathrm{~s}^{-1}, \mathrm{n}=136$ ) and high light (HL, $E_{\mathrm{PAR}}>200$ $\mu \mathrm{mol}$ photons $\mathrm{m}^{-2} \mathrm{~s}^{-1}, \mathrm{n}=30$ ) sample groups. Two initial ratio matrices adjusted for LL and HL conditions were used in the subsequent CHEMTAX analyses of each light group and size fraction. The initial ratio matrices included LL and HL pigment:chl a ratios gathered from the literature (Table 1) and from phytoplankton cultures (Chaetoceros socialis, Leptocylindrus danicus, and Micromonas pusilla) isolated in a neighboring coastal area (Ría de Arousa, NW Spain). CHEMTAX was run 2 consecutive times for each light group and size fraction - the first output ratio matrix being used as the initial matrix in the second analysis. The HPLC method allowed the separation of divinyl (DV) chl a (the exclusive marker of the cyanobacterium Prochlorococcus) from $\mathrm{chl} a$. Thus, zeaxanthin (Zea) 
Table 1. Marker pigments and reference source for the pigment groups included in the CHEMTAX analyses. For pigment abbreviations see Fig. 4 legend

\begin{tabular}{|llll|}
\hline Pigment groups & Main marker pigments & Source species & Reference \\
\hline Diatoms I & Chl $c_{1}$, Fuco & Chaetoceros socialis & M. Zapata (pers. comm) \\
Diatoms II & Chl $c_{3}$, Fuco & Leptocylindrus danicus & M. Zapata (pers. comm) \\
Dinoflagellates & Per & Prorocentrum micans & Schlüter et al. (2000) \\
Haptophytes I & Chl $c_{2}$-MGDG [14:0/18:4], & Emiliania huxleyi & Schlüter et al. (2000), \\
& 19 Hex & & Zapata et al. (2004) \\
Haptophytes II & Chl $c_{2}$-MGDG [14:0/14:0], & Chrysochromulina polylepis & Henriksen et al. (2002), \\
& 19 Hex & & Zapata et al. (2001) \\
Chlorophytes & Chl $b$ & Brachiomonas submarina & Schlüter et al. (2000) \\
Prasinophytes & Chl $b$, Pras & Nano-microplankton: & Henriksen et al. (2002) \\
& & Pseudoscourfieldia marina & Schlüter et al. (2000) \\
Prasinophytes II & Chl $b$, Pras, Uriol & Picoplankton: Pycnococcus provasolii & M. Zapata (pers. comm.) \\
Pelagophytes & 19 buta & Micromonas pusilla & Schlüter et al. (2000) \\
Cryptophytes & Allox & Pelagococcus subviridis & Schlüter et al. (2000) \\
Synechococcus & Zea & Rhodomonas salina & Henriksen et al. (2002) \\
Prochlorococcus & DV Chl a & Synechococcus sp. & Goericke \& Repeta (1992) \\
\hline
\end{tabular}

contributed by Prochlorococcus was estimated prior to performing CHEMTAX analyses and subtracted from total Zea values.

Statistics. The entire data set (including pigments, biomass, physico-chemical variables, and pigment groups) was examined using 1-Pearson r correlation to identify co-variations among variables. All statistical analyses were performed using STATISTICA for Windows, Release 5.0, StatSoft (1995).

\section{RESULTS}

\section{Hydrography and chl a}

Based on temperature and nitrate distribution (Fig. 2A, B) 8 hydrographic periods could be distinguished at the station studied: (I) spring-summer stratification (May to July 2001), (II) summer relaxation (August 2001), (III) late summer upwelling (September 2001), (IV) downwelling and stratified poleward current (October to November 2001), (V) transitional upwelling (November 2001), (VI) homogeneous poleward current (December to February 2001/2002), (VII) winter mixing (March 2002), and (VIII) onset of spring conditions (April 2002). Most of these periods corresponded with significant changes in the chemotaxonomic composition of phytoplankton, particularly in the winter IPC (VI). The biological transition between periods usually took place a week after the physicochemical changes.
HPLC total chl a (TotChl $a=\operatorname{chl} a+$ DV chl $a$ ) values ranged between 1 and $2 \mu g ~^{-1}$ throughout the year. Only during the September upwelling and in spring (April 2002) did chl a values rise to $\sim 3 \mu \mathrm{g} \mathrm{l}^{-1}$, when diatoms where more abundant. DV chl a (Prochlorococcus) never exceeded $100 \mathrm{ng} \mathrm{l}^{-1}$.

Overall, picoplankton and nano-microplankton represented 20 and $80 \%$ of the TotChl a measured between May 2001 and April 2002. The annual trends in chl a concentration differed between size fractions (Fig. 2C, D). Picoplankton chl a showed smoother variations (average $\pm \mathrm{SD}, 89.4 \pm 60.1 \mathrm{ng}$ chl a $\mathrm{l}^{-1}$ ) than the nano-microplankton fraction (359.8 $\pm 433.8 \mathrm{ng} \mathrm{chl}$ a $\mathrm{l}^{-1}$ ). For nano-microplankton (Fig. 2C), maximum chl a values occurred during the

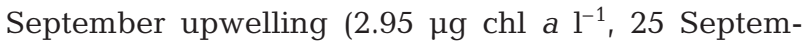
ber 2001, $15 \mathrm{~m}$ depth), with other chl a maxima registering in July and April 2002. In contrast, the maximum picoplankton chl a was measured in March (306 ng chl a l${ }^{-1}, 26$ March 2002, 3 m depth; Fig. 2D), while from July to September and in April 2002 other secondary chl a maxima were observed. Maximum contribution of picoplankton to TotChl a was measured during the October downwelling and in the winter IPC ( $\sim 40 \%$ of mean TotChl a for each period). However, both size classes showed minimum chl a values during the same IPC period (VI). DV chl $a_{\text {, }}$ the marker pigment for Prochlorococcus, showed its maxima in October and November (Periods IV and V, 90.1 ng DV chl a l-1, 30 October 2001, $15 \mathrm{~m}$ depth; Fig. 2E). 

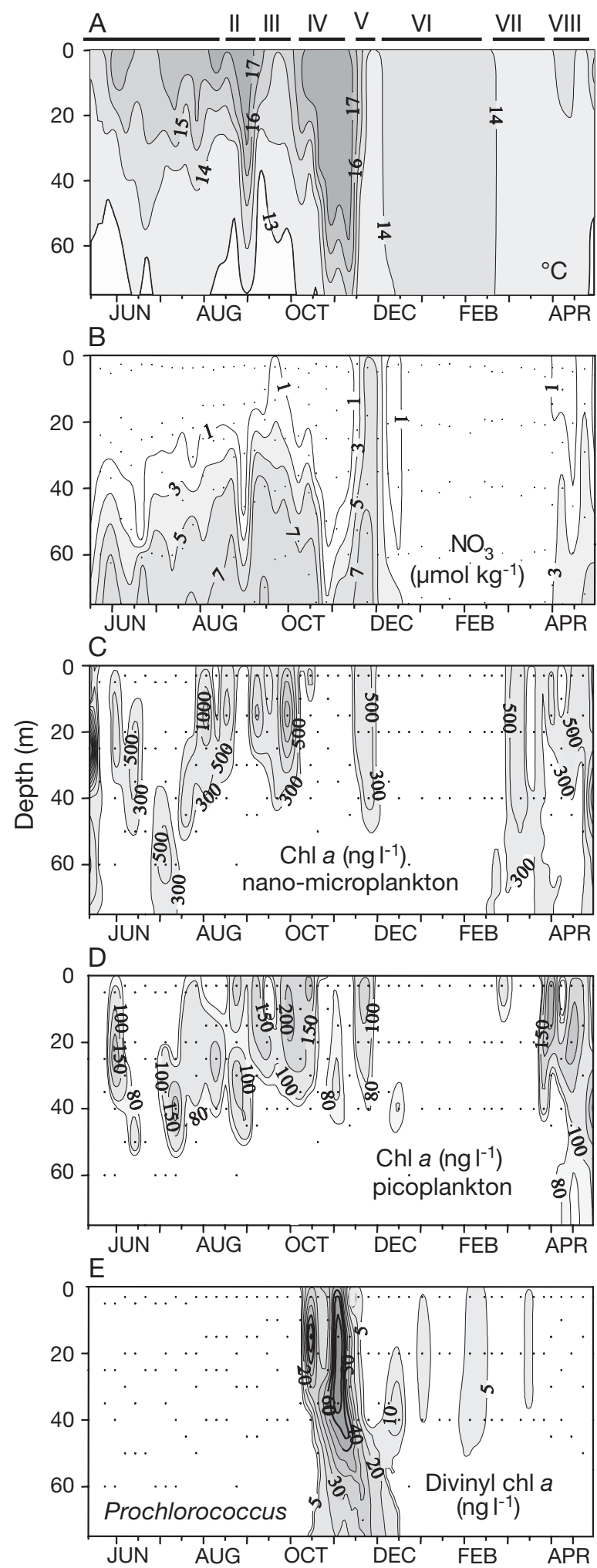

Fig. 2. Temporal distribution (2001 to 2002) of: (A) temperature $\left({ }^{\circ} \mathrm{C}\right)$, (B) nitrates $\left(\mu \mathrm{mol} \mathrm{kg}{ }^{-1}\right)$, (C) nano-microplankton chl a (ng chl $a \mathrm{l}^{-1}$ ), (D) picoplankton chl $a\left(\mathrm{ng} \mathrm{chl} \mathrm{al}^{-1}\right.$ ) and (E) divinyl chl a (ng DV chl $a \mathrm{l}^{-1}$ ). The lengths of each of 8 hydrographic periods (see 'Results' for description) are shown in (A)

\section{Phytoplankton assemblages: light microscopy and carbon biomass}

Picoplankton, nanoplankton, and microplankton accounted for $9.7,63.0$, and $27.3 \%$ of the total autotrophic carbon, respectively. When examining the percentage of these size classes for each seasonal period, microplankton and nanoplankton were co-dominant during the August relaxation and September upwelling periods (Fig. 3). Microplankton carbon showed its lowest contribution during the poleward flow (Period VI), while picoplankton and nanoplankton showed maximum values (18 and $76 \%$ autotrophic $\mathrm{C}$, respectively; Fig. 3).

After examining the phytoplankton groups, the major contributors to autotrophic $\mathrm{C}$ were unidentified nanoflagellates (63\%) and diatoms (22\%). Major diatom species were Leptocylindrus minimus and $L$. danicus, small centric unidentified species and Skeletonema spp., which accounted for 35, 14, and $10 \%$, respectively, of the total diatom $\mathrm{C}$.

The autotrophic species of dinoflagellates represented $3 \%$ of the total autotrophic C. The most relevant species of the total autotrophic dinoflagellate $\mathrm{C}$ were Prorocentrum minimum, Gymnodinium nanum, and Karenia mikimotoi, at 24, 12, and $11 \%$, respectively. Cryptophytes and other minor groups (chryso-

\section{$\%$ Carbon (annual trends)}

I. Spring-summer stratification

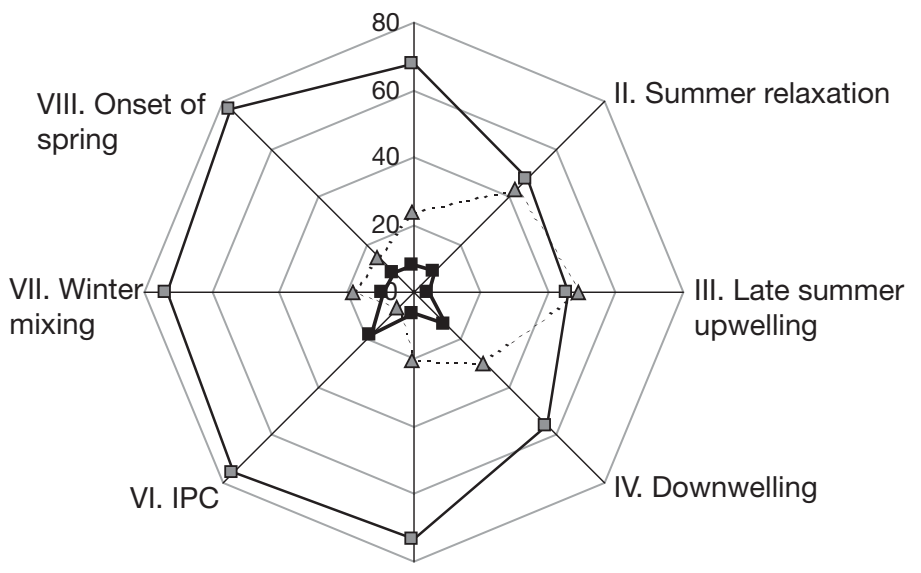

V. Transitional upwelling

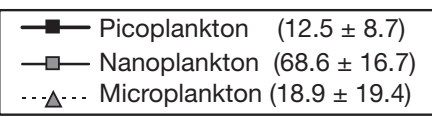

Fig. 3. Percentage contribution of picoplankton, nanoplankton, and microplankton to carbon biomass determined by light microscopy in each hydrographic period. IPC: Iberian Poleward Current. Overall means $( \pm \mathrm{SD})$ for the size fractions are also given 
phytes, raphidophytes, and euglenophytes) contributed only $\sim 1 \%$ of the autotrophic $\mathrm{C}$ biomass.

\section{HPLC pigment composition}

The major pigments in each fraction are shown in Fig. 4. Nano-microplankton and picoplankton were dominated quantitatively by different chlorophylls and carotenoids. The latter were higher in proportion in the nano-microplankton than in the picoplankton (70 and $54 \%$ total accessory pigments, respectively; Fig. 4). Log accessory pigments and log TotChl a were statistically related (slope $=1.180, \mathrm{r}^{2}=0.954, \mathrm{p}<0.001$ ), and, in spite of the distinct contribution of chlorophylls and carotenoids, no significant differences were found between picoplankton and nano-microplankton.

Some pigments were exclusive to a single size group: chl $c_{1}$ and peridinin from the nano-microplankton and uriolide, micromonol, micromonal (the 2 latter only detected in trace amounts), and DV chl $a$ in the picoplankton. For nano-microplankton, chl $C_{2} \quad(50 \%$ total accessory chlorophylls) and fucoxanthin (58\% total carotenoids), both shared by multiple taxonomic groups (diatoms, haptophytes, pelagophytes, chrysophytes, etc.), were the main accessory chlorophyll and carotenoid, respectively (Fig. 4A).
In the picoplankton, chl $b(\sim 40 \%$ total accessory chlorophylls, contributed by green algae) and zeaxanthin (34\% total carotenoids, from cyanobacteria Synechococcus and Prochlorococcus) were the most abundant pigments (Fig. 4B). Non-polar chls $C$ (i.e. chl $C_{2}$-MGDG [14:0/18:4] and chl $C_{2}$-MGDG [14:0/14:0]) were relatively abundant in the nano-microplankton (11\% accessory chlorophylls), but were barely detected in the picoplankton (only 1\%). The HPLC method used in this study did not allow separation of DV chl $b$ (exclusive to Prochlorococcus) from chl $b$. However, the similarity between the visual ultraviolet spectrum of chl $b$ in samples with maxima of DV chl $a$ and that of chl $b$ allowed us to conclude that little or no DV chl $b$ was ever present.

\section{CHEMTAX analysis}

The final ratio (LL and HL) matrices for nanomicroplankton and picoplankton are shown in Tables 2 \& 3, with the corresponding percentage of variation relative to the initial estimations. The annual average of chl a contributed by each pigment group is shown in Fig. 5A,B. Nano-microplankton was 'brown', as groups containing chl $C$ dominated the larger fraction; picoplankton was 'green', as chl $b$-containing groups
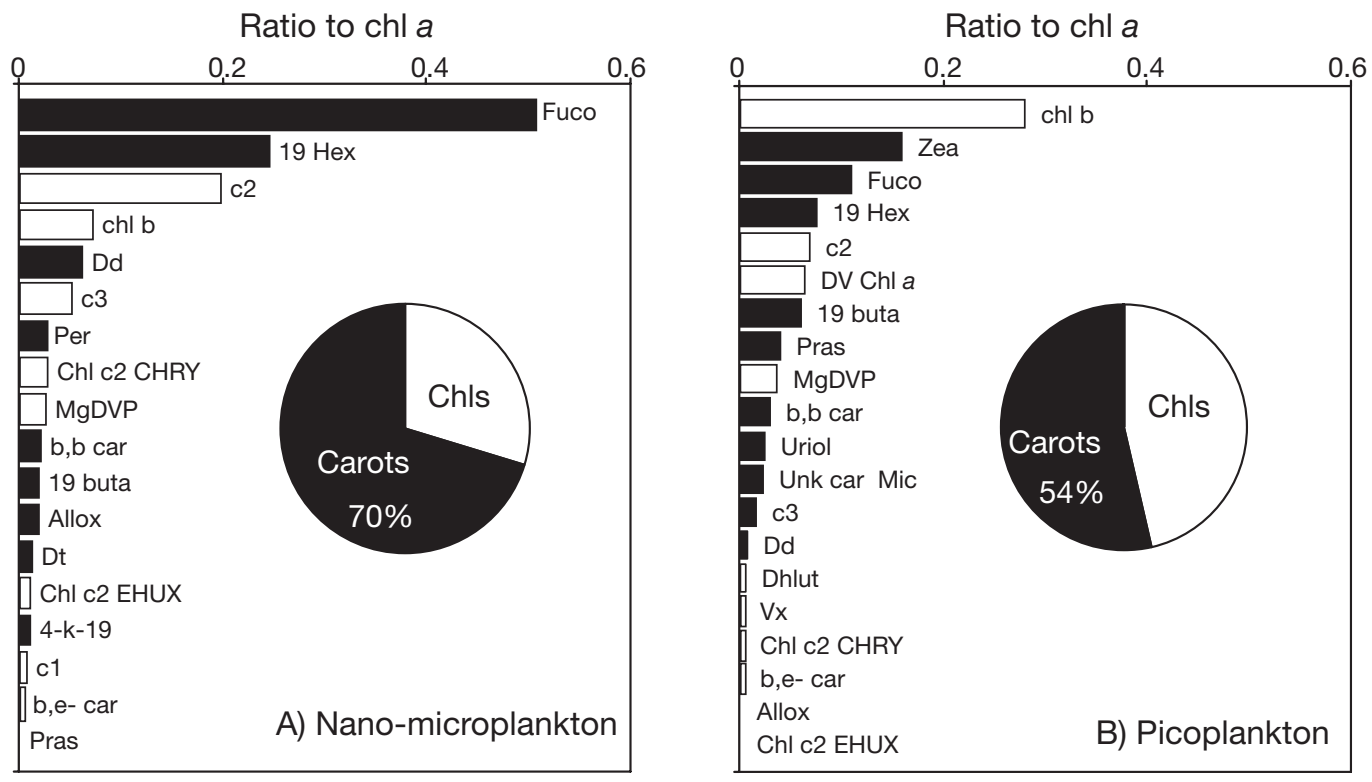

Fig. 4. Accessory pigments to chl a ratios in: (A) nano-microplankton and (B) picoplankton groups. Black and white bars represent carotenoids (Carots) and chlorophylls (chls), respectively. Sector diagrams illustrate the proportion of carotenoids and accessory chlorophylls in both groups (Allox: alloxanthin; b,b car: $\beta, \beta$ carotene; b,e car: $\beta, \varepsilon$ carotene; 19 buta: 19 '-butanoloxy-fucoxanthin; Chl c2 CHRY: chl $c_{2}$-MGDG [14:0/14:0]; Chl c2 EHUX: chl $c_{2}$-MGDG [14:0/18:4]; Dd: diadinoxanthin; Dhlut: dihydrolutein; Dt: diatoxanthin; DV Chl a: divinyl chl a; Fuco: fucoxanthin; 19 Hex: 19'-hexanoyloxy-fucoxanthin; 4-k-19: 4'-keto-hexanoyloxyfucoxanthin; MgDVp: magnesium 3,8-divinylpheoporphytin $a_{5}$ monomethyl ester; Per: peridinin; Pras: prasinoxanthin; Unk car Mic: unknown carotenoid from Micromonas; Uriol: uriolide; Vx: violaxanthin; Zea: zeaxanthin). 
together with cyanobacteria (Synechococcus-like pigments) were the major components. For comparison, diatoms I + II and haptophytes I + II in the nanomicroplankton fraction accounted for $67 \%$ of the total chl $a$ in the annual term, whereas in the picoplankton these represented only $13 \%$.

Significant changes were found in the contribution of each pigment group to the chl a during the sampled period (Fig. 5C, D). In the nano-microplankton, diatoms I + II increased in proportion from the spring-summer stratification to the September upwelling (Periods I to III), but dropped from the October downwelling to the winter poleward current (IV to VI). haptophytes I + II followed inverse trends during these periods. The other pigment groups were minor throughout the year $(<40 \%$ of the total $\mathrm{chl} a)$, with the exception of 2 seasons: the transitional upwelling in
November (V), showing a maximum contribution of dinoflagellates, and the homogeneous poleward current (VI), where cryptophytes and chlorophytes codominated together with haptophytes II.

The picoplankton was dominated most of the year by chlorophytes and synechococcus ( 60\% of the total chl a), whereas prasinophytes II (uriolide-containing prasinophytes, which, with a few exceptions such as the genus Prasinococcus, belonged exclusively to the order Mamiellales, e.g. Micromonas pusilla, Bathycoccus prasinos, Ostreococcus tauri; Latasa et al. 2004), haptophytes, and pelagophytes accounted for approximately $25 \%$ of the total chl a. The most significant changes in pigment group composition were estimated during Periods IV to VI. During the October downwelling (IV) DV chl a from Prochlorococcus appeared first, with maximum contributions (together with pelagophytes)

Table 2. Final ratio matrix (and percentage of variation relative to initial ratios in parentheses; arrows indicate higher or lower ratio) in the nano-microplankton fraction in low light samples and high light samples. (-): pigment absent. For other pigment abbreviations see Fig. 4 legend

\begin{tabular}{|c|c|c|c|c|c|c|c|c|c|c|c|c|}
\hline & $\begin{array}{c}\mathrm{Chl} \\
C_{3}\end{array}$ & $\begin{array}{c}\mathrm{Chl} \\
C_{2}\end{array}$ & $\begin{array}{c}\mathrm{Chl} \\
C_{1}\end{array}$ & $\begin{array}{l}\text { Chl } C_{2}- \\
\text { EHUX }\end{array}$ & $\begin{array}{l}\mathrm{Chl} C_{2}^{-} \\
\mathrm{CHRY}\end{array}$ & Per & $\begin{array}{c}19 \\
\text { buta }\end{array}$ & Fuco & Pras & $\begin{array}{c}19 \\
\text { Hex }\end{array}$ & Allox & $\begin{array}{c}\mathrm{Chl} \\
b\end{array}$ \\
\hline \multicolumn{13}{|c|}{ Low light samples } \\
\hline Diatoms I & - & 0.165 & $\begin{array}{c}0.107 \\
(\downarrow 4 \%)\end{array}$ & - & - & - & - & 0.546 & - & - & - & - \\
\hline Diatoms II & $\begin{array}{c}0.046 \\
(\downarrow 60 \%)\end{array}$ & 0.299 & - & - & - & - & - & $\begin{array}{c}0.932 \\
(\uparrow 20 \%)\end{array}$ & - & - & - & - \\
\hline Haptophytes I & $\begin{array}{c}0.249 \\
(\uparrow 12 \%)\end{array}$ & 0.171 & - & 0.097 & - & - & - & 0.722 & - & 0.236 & - & - \\
\hline Haptophytes II & $\begin{array}{c}0.059 \\
(\downarrow 61 \%)\end{array}$ & $\begin{array}{l}0.149 \\
(\uparrow 7)\end{array}$ & - & - & $\begin{array}{c}0.134 \\
(\uparrow 7 \%)\end{array}$ & - & $\begin{array}{c}0.009 \\
(\uparrow 6 \%)\end{array}$ & $\begin{array}{c}0.129 \\
(\uparrow 7 \%)\end{array}$ & - & $\begin{array}{c}1.281 \\
(\uparrow 58 \%)\end{array}$ & - & - \\
\hline Chlorophytes & - & - & - & - & - & - & - & - & - & - & - & 0.433 \\
\hline Prasinophytes & - & - & - & - & - & - & - & - & 0.322 & - & - & 0.790 \\
\hline Pelagophytes & $\begin{array}{c}0.151 \\
(\downarrow 1 \%)\end{array}$ & 0.316 & - & - & - & - & $\begin{array}{c}0.656 \\
(\uparrow 173 \%)\end{array}$ & 1.241 & - & - & - & - \\
\hline Dinoflagellates & - & 0.111 & - & - & - & 0.442 & - & - & - & - & - & - \\
\hline Cryptophytes & - & 0.060 & - & - & - & - & - & - & - & - & 0.172 & - \\
\hline \multicolumn{13}{|c|}{ High light samples } \\
\hline Diatoms I & - & 0.165 & $\begin{array}{c}0.066 \\
(\downarrow 41 \%)\end{array}$ & - & - & - & - & 0.546 & - & - & - & - \\
\hline Diatoms II & $\begin{array}{c}0.046 \\
(\downarrow 61 \%)\end{array}$ & 0.299 & - & - & - & - & - & $\begin{array}{c}0.929 \\
(\uparrow 20 \%)\end{array}$ & - & - & - & - \\
\hline Haptophytes I & $\begin{array}{c}0.268 \\
(\uparrow 21 \%)\end{array}$ & - & 0.171 & 0.097 & - & - & - & 0.722 & - & 0.276 & - & - \\
\hline Haptophytes II & $\begin{array}{c}0.058 \\
(\downarrow 62 \%)\end{array}$ & $\begin{array}{c}0.155 \\
(\uparrow 11 \%)\end{array}$ & - & - & $\begin{array}{c}0.140 \\
(\uparrow 25 \%)\end{array}$ & - & $\begin{array}{c}0.009 \\
(\uparrow 12 \%)\end{array}$ & $\begin{array}{c}0.082 \\
(\uparrow 12 \%)\end{array}$ & - & $\begin{array}{c}1.074 \\
(\uparrow 57 \%)\end{array}$ & - & - \\
\hline Chlorophytes & - & - & - & - & - & - & - & - & - & - & - & 0.433 \\
\hline Prasinophytes & - & - & - & - & - & - & - & - & 0.317 & - & - & 0.790 \\
\hline Pelagophytes & $\begin{array}{c}0.103 \\
(\downarrow 33 \%)\end{array}$ & 0.316 & - & - & - & - & $\begin{array}{c}0.510 \\
(\uparrow 233 \%)\end{array}$ & 0.317 & - & - & - & - \\
\hline Dinoflagellates & - & 0.093 & - & - & - & 0.375 & - & - & - & - & - & - \\
\hline Cryptophytes & - & 0.060 & - & - & - & - & - & - & - & - & 0.172 & - \\
\hline
\end{tabular}


Table 3. Final ratio matrix (and percentage of variation relative to initial ratios in parentheses; arrows indicate higher or lower ratio) in the picoplankton fraction in: low light samples and high light samples. Arrows indicate higher or lower initial to final ratios. (-): Pigment absent. For pigment abbreviations see Fig. 4 legend

\begin{tabular}{|c|c|c|c|c|c|c|c|c|c|c|}
\hline & \multicolumn{10}{|c|}{ Pigments (final ratio/initial ratio) } \\
\hline & $\mathrm{Chl} c_{3}$ & $\mathrm{Chl} C_{2}$ & Uriol & 19 buta & Fuco & Pras & 19 Hex & Allox & Zea & Chl $b$ \\
\hline \multicolumn{11}{|l|}{ Low light samples } \\
\hline Diatoms II & $\begin{array}{c}0.086 \\
(\downarrow 26 \%)\end{array}$ & 0.299 & - & - & $\begin{array}{c}1.267 \\
(\uparrow 63 \%)\end{array}$ & - & - & - & - & - \\
\hline Haptophytes & $\begin{array}{c}0.099 \\
(\downarrow 35 \%)\end{array}$ & 0.139 & - & 0.008 & 0.121 & - & $\begin{array}{c}0.872 \\
(\uparrow 7 \%)\end{array}$ & - & - & - \\
\hline Chlorophytes & - & - & - & - & - & - & - & - & - & 0.433 \\
\hline Prasinophytes & - & - & - & - & - & 0.438 & - & - & - & 0.790 \\
\hline Prasinophytes II & - & - & 0.210 & - & - & $\begin{array}{c}0.276 \\
(\downarrow 40 \%)\end{array}$ & - & - & - & 0.914 \\
\hline Pelagophytes & $\begin{array}{c}0.130 \\
(\downarrow 16 \%)\end{array}$ & 0.316 & - & $\begin{array}{c}0.530 \\
(\uparrow 121 \%)\end{array}$ & $\begin{array}{c}0.437 \\
(\downarrow 65 \%)\end{array}$ & - & - & - & - & - \\
\hline Cryptophytes & - & 0.060 & - & - & - & - & - & 0.172 & - & - \\
\hline Synechococcus & - & - & - & - & - & - & - & - & 0.457 & - \\
\hline Prochlorococcus ${ }^{\mathrm{a}}$ & - & - & - & - & - & - & - & - & 0.380 & - \\
\hline \multicolumn{11}{|l|}{ High light samples } \\
\hline Diatoms II & $\begin{array}{c}0.076 \\
(\downarrow 34 \%)\end{array}$ & 0.299 & - & - & $\begin{array}{c}1.186 \\
(\uparrow 52 \%)\end{array}$ & - & - & - & - & - \\
\hline Haptophytes & $\begin{array}{c}0.091 \\
(\downarrow 40 \%)\end{array}$ & 0.139 & - & 0.008 & 0.073 & - & $\begin{array}{c}1.035 \\
(\uparrow 51 \%)\end{array}$ & - & - & - \\
\hline Chlorophytes & - & - & - & - & - & - & - & - & - & $\begin{array}{c}0.336 \\
(\uparrow 8 \%)\end{array}$ \\
\hline Prasinophytes & - & - & - & - & - & 0.439 & - & - & - & 0.568 \\
\hline Prasinophytes II & - & - & $\begin{array}{c}0.206 \\
(\uparrow 44 \%)\end{array}$ & - & - & $\begin{array}{c}0.095 \\
(\downarrow 70 \%)\end{array}$ & - & - & - & 0.523 \\
\hline Pelagophytes & $\begin{array}{c}0.059 \\
(\downarrow 62 \%)\end{array}$ & $\begin{array}{c}0.308 \\
(\downarrow 3 \%)\end{array}$ & - & $\begin{array}{c}0.471 \\
(\uparrow 208 \%)\end{array}$ & $\begin{array}{c}0.249 \\
(\downarrow 22 \%)\end{array}$ & - & - & - & - & - \\
\hline Cryptophytes & - & 0.060 & - & - & - & - & - & 0.339 & - & - \\
\hline Synechococcus & - & - & - & - & - & - & - & - & 0.939 & - \\
\hline Prochlorococcus ${ }^{\mathrm{a}}$ & - & - & - & - & - & - & - & - & 0.760 & - \\
\hline
\end{tabular}

in October and November. During establishment of the homogeneous poleward current (VI) chlorophytes attained their maximum (54\% total $\mathrm{chl}$ a).

\section{Chl a:C ratios}

Chl a estimated by the conventional fluorescence technique (FLUO) was, on average, twice as high as the corresponding HPLC chl a values (FLUO $=2.58 \times$ HPLC $\left.+0.18, r^{2}=0.83, n=165\right)$. Consequently, FLUO and HPLC chl a:C ratios (Fig. 6A, B) differed significantly, varying between 0.004 and 0.067 and 0.001 and 0.090, respectively.

When calculating chl a:C ratios for total 'diatoms' (including diatoms I + diatoms II + picoplanktonic diatoms II) estimated by CHEMTAX, we found that $\sim 50$ of the samples had chl a data with no, or with unrealistically low, carbon correspondence (chl a:C < 0.001). The opposite ( $\mathrm{C}$ data without chl a) occurred for dinoflagellates (Fig. 6C). This means that in one-third of the samples, chl a contributed by diatoms in CHEMTAX did not correspond to any microscopic counts, whereas for dinoflagellates this was quite the opposite. Two distinct trends were revealed when plotting $\mathrm{C}$ versus chl a for diatoms (Fig. 6C): chl a:C ratios were unusually low in a group of medium to high carbon values registered at the surface (3 $\mathrm{m}$ depth, belonging to the HL sample group), whereas other data (mostly from $15 \mathrm{~m}$ depth) exhibited higher chl a:C ratios.

In the nano-microplankton, some pigment groups showed significant relationships with available carbon 

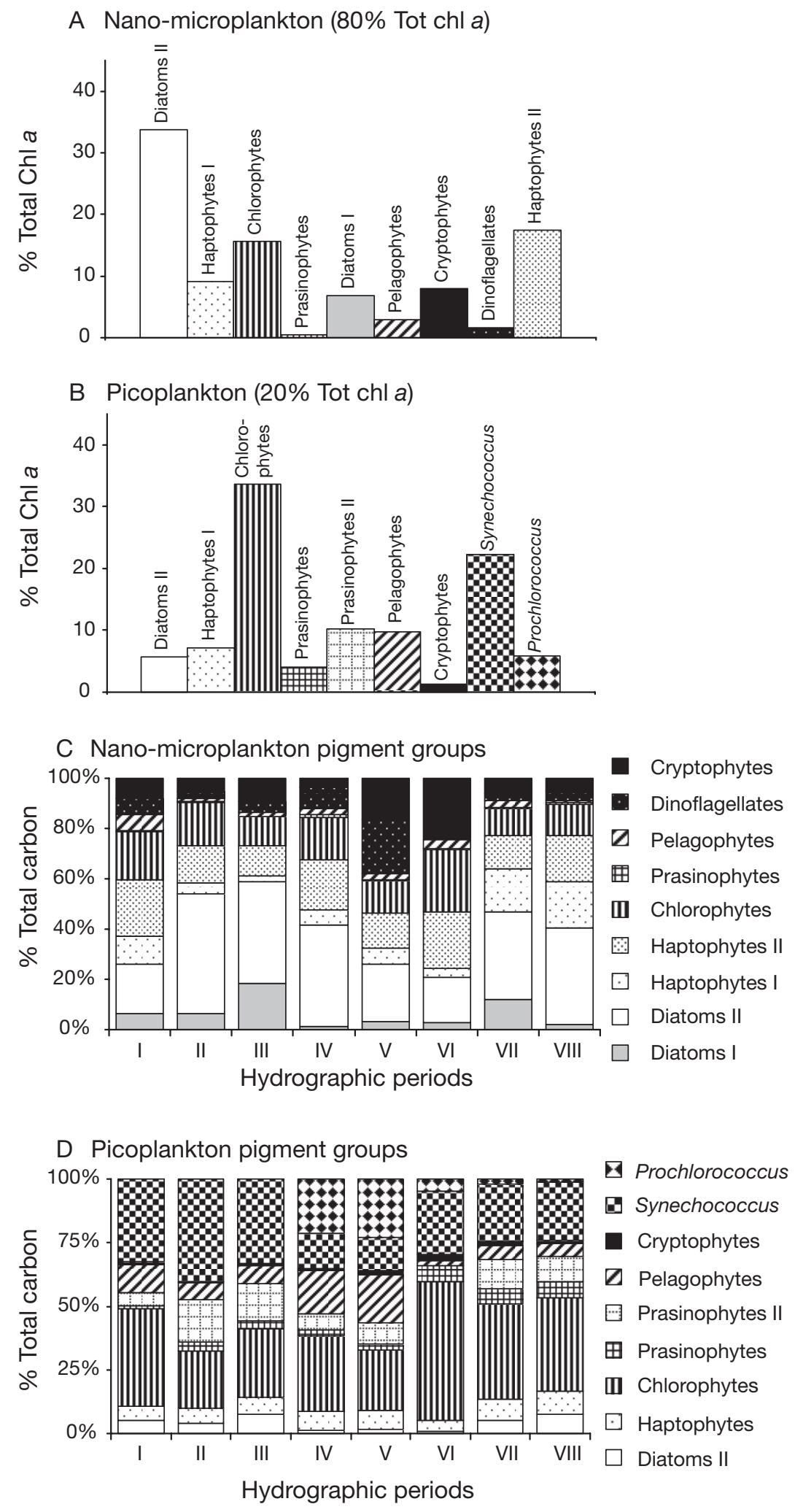

Fig. 5. Annual percentage to total chl a contributed by CHEMTAX pigment groups within each size fraction: (A) nano-microplankton and (B) picoplankton. The percentage contribution of these pigment groups during Hydrographic Periods I to VIII: (C) nano-microplankton and (D) picoplankton biomass. This was the case for diatoms $\mathrm{I}$ and diatoms II with diatom $\mathrm{C}\left(\mathrm{r}^{2}=\right.$ 0.41, $\mathrm{p}<0.001, \mathrm{n}=167$, in both cases) and dinoflagellates with autotrophic dinoflagellate C $\left(\mathrm{r}^{2}=0.56, \mathrm{p}<0.001, \mathrm{n}\right.$ $=167$ ). In the picoplankton, chl a contributed by Synechococcus did not match cyanobacterial $\mathrm{C}$, but a significant relationship between zeaxanthin and cyanobacterial $\mathrm{C}$ was found $\left(\mathrm{r}^{2}=\right.$ 0.61, $\mathrm{p}<0.001, \mathrm{n}=167$ ).

\section{DISCUSSION}

\section{Size-fractionated phytoplankton biomass}

In open ocean regions of the NASE ecological province (North Atlantic Subtropical Gyral East; Li \& Harrison 2001) phytoplankton biomass is largely dominated by picoplankton, specifically by the cyanobacterium Prochlorococcus (Zubkov et al. 2000, Morán et al. 2004). Our study, although in the northeasternmost area of NASE, was conducted in temperate neritic waters influenced by the seasonal upwelling and continuous exchange of coastal phytoplankton populations (shortened only during the winter IPC; Álvarez-Salgado et al. 2003). In this region, as in other temperate areas of the world's oceans (Barlow et al. 2004, Dandonneau et al. 2004), nanoplankton communities usually dominated the autotrophic biomass year-round (Tilstone et al. 2003), while picoplankton remained a low fraction of the total autotrophic $\mathrm{C}$ that attains greater importance during the stratified (IV) and homogeneous IPC (VI) (Fig. 3). Only during the summer upwelling, when annual maxima of biomass are registered (Varela 1992), do microplanktonic diatoms sometimes dominate the autotrophic biomass, as occurred in the present study. Teira et al. (2001) reported a similar dominance of nano-microplankton $\mathrm{C}$ biomass during the summer upwelling for the same study site. The latter authors also found a major contribution of picoplankton in autumn and 

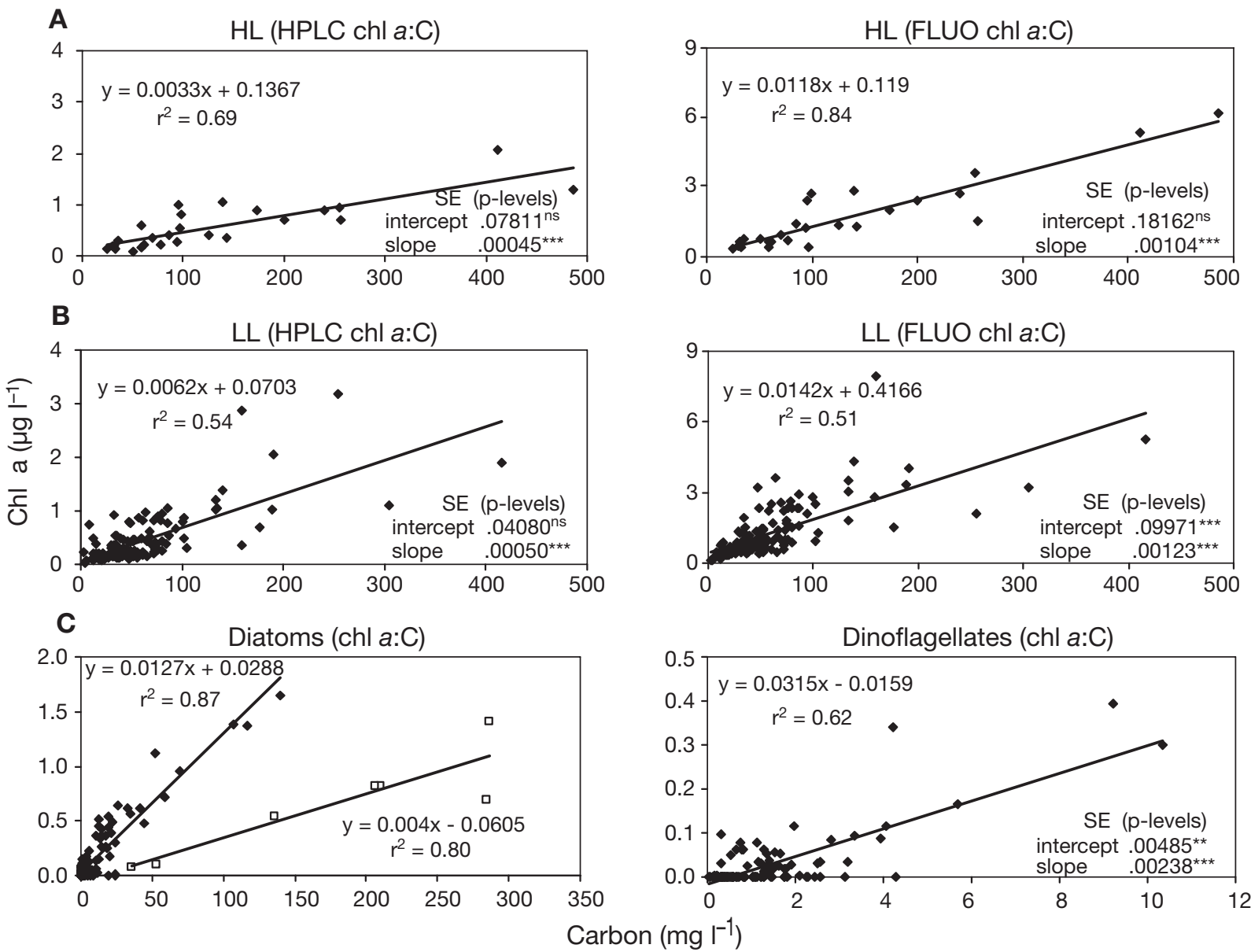

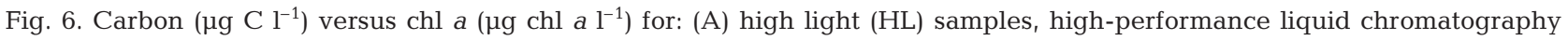
(HPLC)- and in situ fluorescence (FLUO)-determined estimates of chl $a_{\text {, }}$ (B) low light (LL) samples, HPLC- and in situ FLUOdetermined estimates of $\mathrm{chl} a$, and (C) diatoms (including total chl a estimated by CHEMTAX of diatoms I + diatoms II +

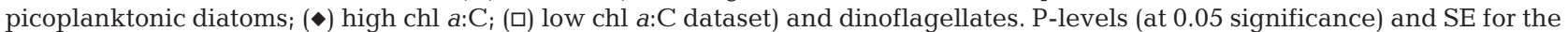
intercept and slope are shown in each panel, except for diatoms (SE intercept $=0.00880^{* * *}$, SE slope $=0.00041^{* * *}$ for high chla $a$ :C series [^]; SE intercept $=0.17860^{\text {ns }}$, SE slope $=0.00091^{* *}$ for low chl $a$ :C series [ᄆ] )

during stratified IPC conditions. Calvo-Díaz et al. (2004) reported $12 \%$ picoplankton to total autotrophic C between March and April 2002 at their westernmost stations, slightly north of our study. During the same months (Periods VII \& VIII in the present study) we determined $\sim 8 \%$ mean contribution of picoplankton to total autotrophic carbon (Fig. 3).

\section{Seasonal succession of phytoplankton groups: impact of IPC}

Size-fractionated pigments, light microscopy, and carbon analyses enabled us to describe the seasonal succession and concomitant changes in the composition and size structure of phytoplankton communities on the NW Iberian shelf. Spring-summer stratified waters were dominated by nanoplankton (hapto- phytes, chlorophytes, and diatoms II), with low biomass of picoplankton (chorophytes and Synechococcus). In fact, chl $b$ - and Zea-containing pigment groups represented $\sim 85 \%$ picoplanktonic chl a (Fig. 5B), confirming these as diagnostic pigments for picoplankton (Vidussi et al. 2001, Barlow et al. 2004).

Increased microplankton contribution to the phytoplankton $\mathrm{C}$ biomass during summer upwelling (Periods II to III) led diatoms ( $\mathrm{Chl} \mathrm{C}_{3}$-containing diatoms II, particularly the genus Leptocylindrus) to dominate the annual biomass maxima, as had been described for NW Iberian waters (e.g. Varela 1992). In the picoplankton, the increase in prasinophytes II and diatoms II was linked to the transition from stratification to summer upwelling. In autumn (Periods IV to V), dinoflagellates and cryptophytes were indeed characteristic groups in the picoplankton, together with prochlorococcus and pelagophytes. 
The homogenous winter IPC (Period VI) should be discussed separately, due to its overall influence on the composition and size distribution of phytoplankton (Figs. 3 \& 5C, D), with the lowest chl $a$ and C concentrations during the annual cycle. Low chl a values (Tilstone et al. 2003, Calvo-Díaz et al. 2004) and the dominance of tiny cells have already been reported for the poleward current (Álvarez-Salgado et al. 2003, CalvoDíaz et al. 2004). The convergence front on the slope created by the IPC effectively isolates coastal phytoplankton from IPC populations (Álvarez-Salgado et al. 2003). It is known that the winter IPC is dominated by small flagellates, while large diatoms and autotrophic dinoflagellates are confined for the most part to inner coastal waters. In accordance with these observations during the homogenous IPC (Period VI), diatoms greatly declined and dinoflagellates were absent. Microplankton was almost absent from the homogenous IPC; marker pigments allowed nanoplankton (chlorophytes, cryptophytes, and Chrysochromulina-type haptophytes II) and picoplankton groups (chlorophytes overwhelming other eukaryotic groups and Synechococcus) associated with the IPC to be identified. Interestingly, prasinophytes II (Order Mamiellales), widely abundant throughout most of the year, disappeared in the winter IPC.

\section{Picoplanktonic populations}

The Eastern North Atlantic Central Water of subtropical origin $\left(\mathrm{ENACW}_{\mathrm{st}}\right)$, as the source of the poleward flow, appears to provide the inoculums of small cells, low nutrients, low chl $a$, and the biomass characteristic of the IPC (Álvarez-Salgado et al. 2003). We might expect significant numbers of prochlorophytes to be associated with the poleward flow, given its subtropical origin, but, instead, these organisms fade out during Period VI.

Prochlorococcus populations are known to decline north of $45^{\circ} \mathrm{N}$, due to lower seawater temperatures (Parténsky et al. 1999). Calvo-Díaz et al. (2004) uniquely detected prochlorophytes at their westernmost stations $\left(<43^{\circ} \mathrm{N}\right)$, but not on the northern Iberian coast $\left(>43^{\circ} \mathrm{N}\right)$, where picoplankton actually dominated TotChl a. These authors identified Synechococcus as the most abundant picoplankter in our study area, generally reflecting our results, although, as they did not study eukaryotic groups, chlorophytes were absent from their study.

Prochlorococcus was not found in the southern Bay of Biscay, North Spain (Rodríguez et al. 2003b) either inside or surrounding the mesoscale structure of a slope water oceanic eddy (SWODDY), derived from jet-like extensions of the poleward flow. Our annual dataset showed that Prochlorococcus was not primarily associated with the core of the winter IPC, as suggested by Calvo-Díaz et al. (2004) in a late winter survey. Rather, Prochlorococcus populations appeared on the inner shelf and on the western Iberian coast during the second part of the year, associated with autumn downwelling conditions (October to November in this survey). Later, once the winter IPC had set in, the main Prochlorococcus populations would be gradually washed offshore, with a weaker DV chl a signal still detected in the homogenous IPC. Finally, coastal Prochlorococcus populations disappeared in late winter, probably due to unfavorable environmental conditions (i.e. decreasing temperatures). Their absence would also be influenced by colder and less salty waters of continental origin, intruding on the inner shelf areas as a buoyancy plume (Peliz et al. 2005). In fact, DV chl a has never been reported in previous HPLC pigment analyses of the Rías de Pontevedra (Rodríguez et al. 2003a) or Arousa (M. Zapata pers. comm.).

Phytoplankton pigments at open ocean and coastal sites of the NE Atlantic Ocean have been reported elsewhere (e.g. Barlow et al. 2004, Gibb et al. 2000, Riegman \& Kraay 2001). These studies generally indicate a dominance of $19^{\prime}$-hexanoyloxy-fucoxanthin (19 Hex) and fucoxanthin (Fuco) (prymnesiophytes and diatoms) in the temperate open ocean (e.g. Gibb et al. 2000, Riegman \& Kraay 2001). Coastal sites are more heterogeneous, and several groups (e.g. dinoflagellates, cryptophytes, chl b-containing algae, and Synechococcus) alternate with diatoms as the most abundant taxa (Schlüter et al. 2000).

Much less information is available for picoeukaryotes than for their prokaryotic counterparts (Veldhuis et al. 2005). A few authors who have performed sizefractionated pigment analyses on NE Atlantic samples (Brunet \& Lizon 2003, Rodríguez et al. 2003a, Not et al. 2004) highlight the prevalence of chlorophytes (particularly prasinophytes; Rodríguez et al. 2003a, Not et al. 2004) in coastal picoeukaryotic populations, along with variable amounts of 19'-butanoloxy-fucoxanthin 19 Buta-, 19 Hex- (chrysophytes and haptophytes; Brunet \& Lizon 2003), and Fuco-containing groups (diatomlike pigments; Rodríguez et al. 2003a).

Varela (1992) enumerates Chlorophyceae, Primnesiophyceae, Chrysophyceae, and Cryptophyceae as some of the most common microflagellates $(<10 \mu \mathrm{m})$ identified on the Galician shelf. However, to our knowledge, this is the first report detailing specific size-fractionated pigment groups and their abundance in the NASE, particularly for the NW Iberian peninsula. Until now the results available originated from estuarine samples (Ría de Pontevedra; Rodríguez et al. 2003a). The most important differences between estu- 
arine and neritic waters are: (1) the contribution of picoplankton to TotChl $a$ is double that found in our study $(29 \% \pm 17 \%$ in comparison with $13 \% \pm 10 \%$ TotChl $a$ in the Ría de Pontevedra); (2) the contribution of the picoplanktonic pigment groups diatoms I + II to chl $a$ in the ría is 4 times higher ( $>25 \%$ TotChl a relative to $6 \%$ in the present study); and (3) the exclusive presence of Synechococcus-type cyanobacteria in the ría, whereas Prochlorococcus is also present in shelf waters. These differences are explained by the environmental conditions in the rías (semi-enclosed and shallower embayments influenced by river runoff and continental discharges), which increase the productivity and size of phytoplankton relative to offshore shelf waters (Tilstone et al. 2003). Most of the new pigment information we gained in this study originates from a variety of chl $c$ compounds ( $\mathrm{chl} c_{1}$, $\mathrm{chl} c_{3}$, $\mathrm{chl} c_{2}$-MGDG [14:0/18:4] \& [14:0/18:4]). Our results demonstrate that chl $C_{1}$ helps to discriminate a group called 'diatoms I' from other chl $C$-containing groups (see also Riegman \& Kraay 2001, Veldhuis \& Kraay 2004). Additional diagnostic pigments for haptophytes, the non-polar chls $C$, first reported in the NE Atlantic (Gieskes \& Kraay 1986), are also readily detected in natural samples.

Chl $C_{2}$-MGDG [14:0/14:0], the marker for haptophytes II and almost exclusive to the genus Chrysochromulina (Zapata et al. 2001, 2004), was widely present in the nano-microplankton fraction. This suggests that Chrysochromulina species were a dominant component of nanoplanktonic haptophytes, in agreement with a previous publication concerning the southern Bay of Biscay (Rodríguez et al. 2003b). Chl $c_{2}$-MGDG [14:0/18:4] from haptophytes I, a typical winter group in our study, pointed towards Emiliania huxleyi, the genus Phaeocystis, and to certain other Chrysochromulina species in the same season (Zapata et al. 2004). In turn, non-polar chls $C$ were barely detected in the picoplankton, and we could not hypothesize on a particular haptophyte genus.

\section{Pigment ratios}

\section{Accessory pigment:chl a}

As pigment:chl a ratios were determined based on initial estimates from cultures (Table 1), output CHEMTAX ratios (Tables $2 \& 3$ ) do not exclusively indicate photoacclimation trends. However, these values, on the whole, exhibited the expected light-dependent responses (i.e. lower accessory chlorophylls in HL vs. LL, although some exceptions have been reported; e.g. Schlüter et al. 2000). In the case of Fuco and 19 Hex, a general pattern from cultures (Schlüter et al. 2000, Henriksen et al. 2002) and CHEMTAX studies
(Llewellyn et al. 2005) indicates that diatoms and haptophytes increase Fuco:chl a ratios in low light and deep samples, the converse being true for $19 \mathrm{Hex}$. This result was also obtained in our study, with the exception of haptophytes II, which retained higher 19 Hex:chl a ratios in LL samples. This pigment group (and picoplanktonic haptophytes) was estimated using Chrysochromulina ratios, a haptophyte genus that does not follow the general rule above (Henriksen et al. 2002). In a recent North Atlantic survey (Lutz et al. 2003), no significant differences were found in 19 Hex:chl a ratios between surface and deep samples. The photoacclimation patterns in haptophytes are thus species dependent and a likely explanation for the variable or constant $19 \mathrm{Hex}$ :chl a ratios along vertical profiles in contrasting oceanic areas.

\section{Chl $a: C$}

The usefulness of chemotaxonomy to estimate phytoplankton composition and biomass has been assessed comparing pigment analyses with carbon estimated from light microscopy (Garibotti et al. 2003, Llewellyn et al. 2005) and flow cytometry (Veldhuis et al. 2005). Despite variations of pigment content relative to carbon and intrinsic discrepancies between techniques, more accurate characterization of phytoplankton assemblages and important ecophysiological information can be gained from chl a:C ratios, such as carbon-based ocean productivity from remote sensing (Garibotti et al. 2003). In the present paper, the range of variability in estimated chl $a$ :C ratios was similar to that reported by Llewellyn et al. (2005) for NE Atlantic samples. Different subsets of chl a:C data have been distinguished in previous studies to accommodate for variations in pigment content per cell due to environmental factors and changes in species composition (Garibotti et al. 2003, Llewellyn et al. 2005). In the present study, a stronger linear relationship between chl $a$ and $C$ values was obtained for HL samples, as these included fewer fluctuating irradiances than LL samples. Lower variability in cellular pigment content relative to $\mathrm{C}$ would explain this stronger relationship in HL samples, as was also discussed by Llewellyn et al. (2005).

The slope of the HPLC-chl a:C relationship (Fig. 6) was in the lower range obtained for algal cultures (Cloern et al. 1995), the slope of FLUO-chl a:C ratios being closer to previous results for the NE Atlantic (Llewellyn et al. 2005). Apart from intrinsic errors in carbon determination, this may suggest that our HPLC values were somewhat lower than expected for this area. It must also be borne in mind that systematic fluorometric overestimates of chl $a_{\text {, }}$ in comparison with HPLC estimates, are usually reported due to interferences with 
DV chl $a$ and/or high concentrations of chls $C$, as may also be the case in our study (Latasa et al. 1996, Stuart et al. 2004). Carbon and chl a biomass estimates of individual pigment groups agree in some cases, e.g. diatoms, but significant discrepancies have been reported for other classes (Garibotti et al. 2003, Llewellyn et al. 2005). In the case of diatoms, C and chl a biomass estimates match fairly well, except when significant contributions to Fuco by other groups are observed (Garibotti et al. 2003). The low chl a:C dataset for diatoms in our surface samples (Fig. 6C) corresponded with different dominant species, so photoacclimation reduction of chl a:C ratios in HL conditions would be the likely explanation for their distinct chl a:C ratios (Llewellyn et al. 2005). Thus, for diatoms only, and after splitting natural samples into 2 depth groups, carbon biomass estimates may be inferred from their contribution to chl a as calculated by CHEMTAX. In turn, the relationship between chl $a$ and $\mathrm{C}$ estimates for dinoflagellates was blurred, probably due to difficulties in distinguishing some autotrophic and heterotrophic species and the presence of non-peridinin-containing species (e.g. Karenia mikimotoi, not included in the pigment group dinoflagellates), as discussed previously (Garibotti et al. 2003, Llewellyn et al. 2005).

\section{CONCLUSIONS}

Size-fractionated carbon analyses indicated that nanoplanktonic organisms accounted for a major portion of the autotrophic biomass in the NW Iberian shelf, and chemotaxonomy revealed that diatoms ( $\mathrm{chl} \mathrm{C}_{3}$-type pigment) and haptophytes (particularly Chrysochromulina-type pigment) dominated in terms of the relative chl a contribution. However, during some hydrographic periods, particularly once the IPC signal in autumn-winter has been detected, major changes in size structure and composition of phytoplankton populations were evidenced, with a simultaneous reduction of microplanktonic populations and higher abundance of picoplanktonic cells (namely chlorophytes) during the IPC period. We conclude that a seasonal succession in the smaller groups takes place in the study area, similar to that observed for larger organisms. However, the taxonomical and pigmentary composition remains quite different in picoeukaryotes, which are dominated by chl $b$-containing groups (chlorophytes and prasinophytes), compared with nano-microeukaryotes, which characterized by chl $C$-containing organisms. The specific gene losses of green plastids relative to red plastids have been suggested as the main reason for their increased portability and the dominance of chl $C$-containing plastids in modern eukaryotic algae
(Grzebyk et al. 2003). However, these reductive traits in green plastids would imply an evolutionary advantage in a picoplanktonic cell whose tiny size forces reduction and simplification at all levels. Elucidating the ecophysiological and molecular traits that underlie this apparent success of chl $b$ - versus chl $c$-containing picoeukaryotes constitutes one of the most promising challenges in the coming era of molecular-ecological studies of phytoplankton.

Acknowledgements. We thank the members of the oceanography group at the Instituto de Investigacións Mariñas who participated in the sampling and analysis of nutrients, and $\mathrm{M}$. Penabad for her skillful technical help in HPLC analysis. We thank E. A. Barbour for spelling and grammar checks. We also thank 2 anonymous reviewers whose comments significantly improved the final paper. Financial support for this work came from the Spanish DYBAGA project (MAR99-1039-C0201) and from the EU HABILE project (EVK3-CT-2001-00063). B.G.C. was funded by a pre-doctoral I3P fellowship of CSICESF.

\section{LITERATURE CITED}

Álvarez-Salgado XA, Figueiras FG, Pérez FF, Groom S and 10 others (2003) The Portugal coastal counter current off NW Spain: new insights on its biogeochemical variability. Prog Oceanogr 56:281-321

Barlow RG, Aiken J, Moore GF, Holligan PM, Lavender S (2004) Pigment adaptations in surface phytoplankton along the eastern boundary of the Atlantic Ocean. Mar Ecol Prog Ser 281:13-26

Bidigare RR, Ondrusek ME, Brooks JR (1993) Influence of the Orinoco River outflow on distribution of algal pigments in the Caribbean Sea. J Geophys Res 98:2259-2269

Bode A, Casas B, Fernandez F, Marañón E, Serret P, Varela M (1996) Phytoplankton biomass and production in shelf waters off NW Spain: spatial and seasonal variability in relation to upwelling. Hydrobiologia 341:225-234

Brunet C, Lizon F (2003) Tidal and diel periodicities of sizefractionated phytoplankton pigment signatures at an offshore station in the southeastern English Channel. Estuar Coast Shelf Sci 56:833-843

Bustillos-Guzmán J, Claustre H, Marty JC (1995) Specific phytoplankton signatures and their relationship to hydrographic conditions in the coastal northwestern Mediterranean Sea. Mar Ecol Prog Ser 124:247-258

Calvo-Díaz A, Morán XAG, Nogueira E, Bode A, Varela M (2004) Picoplankton community structure along the northern Iberian continental margin in late winter-early spring. J Plankton Res 26:1069-1081

Cloern JE, Grenz C, Vidergar-Lucas L (1995) An empirical model of the phytoplankton chlorophyll:carbon ratio-the conversion factor between productivity and growth rate. Limnol Oceanogr 40:1313-1321

Dandonneau Y, Deschamps PY, Nicolas JM, Loisel H, Blanchot J, Montel Y, Thieuleux F, Becu G (2004) Seasonal and interannual variability of ocean color and composition of phytoplankton communities in the North Atlantic, Equatorial Pacific and South Pacific. Deep-Sea Res II 51:303-318

Figueiras FG, Pazos Y (1991) Microplankton assemblages in three Rías Baixas (Vigo, Arousa and Muros, Spain) with a subsurface chlorophyll maximum: their relationships to hydrography. Mar Ecol Prog Ser 76:219-233 
Fry JC (1990) Direct methods and biomass estimation. Methods Microbiol 22:41-85

Garibotti IA, Vernet M, Kozlowski WA, Ferrario ME (2003) Composition and biomass of phytoplankton assemblages in coastal Antarctic waters: a comparison of chemotaxonomic and microscopic analyses. Mar Ecol Prog Ser 247:27-42

Gibb SW, Barlow RG, Cummings DG, Rees NW, Trees CC, Holligan P, Suggett D (2000) Surface phytoplankton pigment distributions in the Atlantic Ocean: an assessment of basin scale variability between $50^{\circ} \mathrm{N}$ and $50^{\circ} \mathrm{S}$. Prog Oceanogr 45:339-368

Gieskes WW, Kraay GW (1986) Analysis of phytoplankton pigments by HPLC before, during and after mass occurrence of the microflagellate Corymbellus aureus during the spring bloom in the open northern North Sea in 1983. Mar Biol 92:45-52

Goericke D, Repeta DJ (1992) The pigments of Prochlorococcus marinus: the presence of divinyl chlorophyll $a$ and $b$ in a marine prochlorophyte. Limnol Oceanogr 37:425-433

Grzebyk D, Schofield O, Vetriani C, Falkowski PG (2003) The Mesozoic radiation of eukaryotic algae: the portable plastid hypothesis. J Phycol 39:259-267

Hansen HP, Grasshoff K (1983) Automated chemical analysis. In: Grasshoff K, Ehrardt M, Kremling K (eds) Methods of seawater analysis. Verlag Chemie, Weinheim, p 347-395

Henriksen P, Riemann B, Kaas H, Sørensen HM, Sørensen HL (2002) Effects of nutrient-limitation and irradiance on marine phytoplankton pigments. J Plankton Res 24: 835-858

Hillebrand H, Dürselen CD, Kirschtel D, Pollingher U, Zohary $\mathrm{T}$ (1999) Biovolume calculation for pelagic and benthic microalgae. J Phycol 35:403-424

Jeffrey SW (1997) Chlorophyll and carotenoid extinction coefficients. In: Jeffrey SW, Mantoura RFC, Wright SW (eds) Phytoplankton pigments in oceanography: guidelines to modern methods. UNESCO, Paris, p 595-596

Joint I, Groom SB, Wollast R, Chou L, Tilstone GH, Figueiras FG, Loijens L, Smyth TJ (2002) Response of phytoplankton production to periodic upwelling and relaxation events at the Iberian shelf break: estimates by the ${ }^{14} \mathrm{C}$ method and by satellite remote sensing. J Mar Syst 32:219-238

Latasa M, Bidigare RR, Ondrusek ME, Kennicutt MC (1996) HPLC analysis of algal pigments: a comparison exercise among laboratories and recommendations for improved analytical performance. Mar Chem 51:315-324

Latasa M, Scharek R, Le Gall F, Guillou L (2004) Pigment suites and taxonomic groups in Prasinophyceae. J Phycol 40:1149-1155

Lessard EJ, Swift E (1986) Dinoflagellates from the North Atlantic classified as phototrophic and heterotrophic by epifluorescence microscopy. J Plankton Res 8:1209-1215

Li WKW, Harrison WG (2001) Chlorophyll, bacteria and picophytoplankton in ecological provinces of the North Atlantic. Deep-Sea Res II 48:2271-2293

Llewellyn CA, Fishwick JR, Blackford JC (2005) Phytoplankton community assemblage in the English Channel: a comparison using chl a derived from HPLC-CHEMTAX and carbon derived from microscopy cell counts. J Plankton Res 27:103-119

Lorenzo LM, Arbones B, Tilstone GH, Figueiras FG (2005) Across-shelf variability of phytoplankton composition, photosynthetic parameters and primary production in the NW Iberian upwelling system. J Mar Syst 54:157-173

Lutz VA, Sathyendranath S, Head EJH, Li WKW (2003) Variability in pigment composition and optical characteristics of phytoplankton in the Labrador Sea and the Central North Atlantic. Mar Ecol Prog Ser 260:1-18
Mackey MD, Mackey DJ, Higgins HW, Wright SW (1996) CHEMTAX - a program for estimating class abundance from chemical markers: application to HPLC measurements of phytoplankton. Mar Ecol Prog Ser 144:265-283

Morán XAG, Fernández E, Pérez V (2004) Size-fractionated primary production, bacterial production and net community production in subtropical and tropical domains of the oligotrophic NE Atlantic in autumn. Mar Ecol Prog Ser 274:17-29

Mouriño C, Fraga F (1985) Determinación de nitratos en agua de mar. Investig Pesq 49:81-96

Not F, Latasa M, Marie D, Cariou T, Vaulot D, Simon N (2004) A single species, Micromonas pusilla (Prasinophyceae), dominates the eukaryotic picoplankton in the western English Channel. Appl Environ Microbiol 70:4064-4072

Parténsky F, Hess WR, Vaulot D (1999) Prochlorococcus: a marine photosynthetic prokaryote of global significance. Microbiol Mol Biol Rev 63:106-127

Pelegrí JL, Arístegui J, Cana L, González-Dávila M and 6 others (2005) Coupling between the open ocean and the coastal upwelling region off northwest Africa: water recirculation and offshore pumping of organic matter. J Mar Syst 54:3-37

Peliz A, Dubert J, Santos AMP, Oliveira PB, Le Cann B (2005) Winter upper ocean circulation in the western Iberia Basin-fronts, eddies and poleward flows: an overview. Deep-Sea Res I 52:621-646

Prézelin BB, Hofmann EE, Mengelt C, Klinck JM (2000) The linkage between Upper Circumpolar Deep Water (UCDW) and phytoplankton assemblages on the west Antarctic Peninsula continental shelf. J Mar Res 58:165-202

Putt M, Stoecker DK (1989) An experimentally determined carbon:volume ratio for marine 'oligotrichous' ciliates from estuarine and coastal waters. Limnol Oceanogr 34: $1097-1103$

Riegman R, Kraay GW (2001) Phytoplankton community structure derived from HPLC analysis of pigments in the Faroe-Shetland Channel during summer 1999: the distribution of taxonomic groups in relation to physical/chemical conditions in the photic zone. J Plankton Res 23: 191-205

Rodríguez F, Pazos Y, Maneiro J, Zapata M (2003a) Temporal variation in phytoplankton assemblages and pigment composition in a fixed station of the Ría of Pontevedra (NW Spain). Estuar Coast Shelf Sci 58:499-515

Rodríguez F, Varela M, Fernández E, Zapata M (2003b) Phytoplankton and pigment distributions in an anticyclonic Slope Water Oceanic eDDY (SWODDY) in the southern Bay of Biscay. Mar Biol 143:995-1011

Romari K, Vaulot D (2004) Composition and temporal variability of picoeukaryote communities at a coastal site of the English Channel from 18S rDNA sequences. Limnol Oceanogr 49:784-798

Schlüter L, Møhlenberg F, Havskum H, Larsen S (2000) The use of phytoplankton pigments for identifying and quantifying phytoplankton groups in coastal areas: testing the influence of light and nutrients on pigment/chlorophyll $a$ ratios. Mar Ecol Prog Ser 192:49-63

Strathmann RR (1967) Estimating the organic carbon content of phytoplankton from cell volume or plasma volume. Limnol Oceanogr 12:411-418

Stuart V, Ulloa O, Alarcón G, Sathyendranath S, Major H, Head EJH, Platt T (2004) Bio-optical characteristics of phytoplankton populations in the upwelling system off the coast of Chile. Rev Chil Hist Nat 77:87-105

Teira E, Serret P, Fernandez E (2001) Phytoplankton sizestructure, particulate and dissolved organic carbon pro- 
duction and oxygen fluxes through microbial communities in the NW Iberian coastal transition zone. Mar Ecol Prog Ser 219:65-83

Tilstone GH, Figueiras FG, Lorenzo LM, Arbones B (2003) Phytoplankton composition, photosynthesis and primary production during different hydrographic conditions at the Northwest Iberian upwelling system. Mar Ecol Prog Ser 252:89-104

Varela M (1992) Upwelling and phytoplankton ecology in Galician (NW Spain) rías and shelf waters. Bol Inst Esp Oceanogr 8:57-74

Veldhuis MJW, Kraay GW (2004) Phytoplankton in the subtropical Atlantic Ocean: towards a better assessment of biomass and composition. Deep-Sea Res 51:507-530

Veldhuis MJ, Timmermans KR, Croot $\mathrm{P}$, van der Wagt B (2005) Picophytoplankton; a comparative study of their biochemical composition and photosynthetic properties. J Sea Res 53:7-24

Verity PG, Langdon C (1984) Relationships between lorica volume, carbon, nitrogen and ATP content of tintinnids in Narraganssett Bay. J Plankton Res 6:859-868

Verity PG, Robertson CY, Tronzo CR, Andrews MG, Nelson JR, Sieracki ME (1992) Relationships between cell volume and the carbon and nitrogen content of marine

Editorial responsibility: Fereidoun Rassoulzadegan (Contributing Editor), Villefranche-sur-Mer, France photosynthetic nanoplankton. Limnol Oceanogr 37: 1434-1446

Vidussi F, Claustre H, Manca BB, Luchetta A, Marty JC (2001) Phytoplankton pigment distribution in relation to upper thermocline circulation in the eastern Mediterranean Sea during winter. J Geophys Res 106:19939-19956

Zapata M, Rodríguez F, Garrido JL (2000) Separation of chlorophylls and carotenoids from marine phytoplankton: a new HPLC method using a reversed phase $\mathrm{C}_{8}$ column and pyridine-containing mobile phases. Mar Ecol Prog Ser 195:29-45

Zapata M, Edvardsen B, Rodríguez F, Maestro MA, Garrido JL (2001) Chlorophyll $C_{2}$ monogalactosyldiacylglyceride ester (chl $C_{2}$-MGDG) a marker pigment for Chrysochromulina polylepis species (Haptophyta). Mar Ecol Prog Ser 219:85-98

Zapata M, Jeffrey SW, Rodríguez F, Clementson L, Garrido JL, Wright SW (2004) Pigment variability in 37 species (65 strains) of Haptophyta: implications for phylogeny and oceanography. Mar Ecol Prog Ser 270:83-102

Zubkov MV, Sleigh MA, Burkill PH, Leakey RJG (2000) Picoplankton community structure in the Atlantic Meridional Transect: a comparison between seasons. Prog Oceanogr 45:369-386

Submitted: July 27, 2005; Accepted: February 8, 2006

Proofs received from author(s): September 1, 2006 